\title{
Analysis of Oxidative Stress Parameters Depend on Diazepam Application in Rat Serum and Tissue Samples
}

\author{
ÖZNUR GÜNGÖR* ${ }^{*}$ and NURHAYAT ÖZDEMIR
}

Department of Chemistry, Inonu University, Malatya-44280, Turkey

oznur.gungor@inonu.edu.tr

Received 9 April 2013 / Accepted 6 May 2013

\begin{abstract}
The aim of this study was to investigate the effect on antioxidant enzymes and malondialdehyde (MDA) in rat serum and various tissues of chronic diazepam application. Rats were exposed to diazepam intraperitonally twice a day for six weeks. The change in enzyme activity levels was determined. Diazepam was given in $1 \mathrm{mg} / \mathrm{kg}$ doses. In liver tissue, catalase (CAT) activity showed a significant decrease when diazepam group was compared to the control group $(\mathrm{p}<0.05)$. Superoxide dismutase (SOD) activity showed a significant increase in kidney tissue of diazepam group. GPx activity decreased in all tissues when diazepam group was compared to the control group. Although, changes in the level of MDA was not statistically significant in groups. These data indicate that chronic diazepam administration may cause to moderate oxidative stress conditions.
\end{abstract}

Keywords: Diazepam, Catalase activity, Malondialdehyde, Superoxide dismutase, Metabolism in rats

\section{Introduction}

Benzodiazepines are widely prescribed as anxiolytics, sedative hypnotics, anticonvulsants or muscle relaxants ${ }^{1-5}$. Clinical popularity of benzodiazepines has been ascribed to the wide safety margin of their therapeutic index, minimal serious adverse side effects and low potential for physical dependence ${ }^{6}$. Apart from their therapeutic applications, benzodiazepines are often abused by drug addicts. As a consequence, these drugs are frequently involved in both clinical and forensic cases ${ }^{2}$.

Benzodiazepines were first developed as sedatives in the 1960s and quickly gained prominence with drugs such as chlordiazepoxide (Librium) and diazepam (Valium). These drugs were more effective as sedatives than the previously used class of compounds, the barbiturates and had fewer side effects. Yet despite the more favorable side-effect profile, benzodiazepines do have the potential for tolerance and dependence, with side effects that include memory impairment and lingering drowsiness.

Several major metabolites of benzodiazepines possess pharmacological profiles similar to the parent drugs (e.g. $N$-desmethylclobazam (DMCLB) from clobazam (CLB), $\mathrm{N}$-desmethyldiazepam from diazepam). On the other hand, they are now among the most 
commonly prescribed drugs, which increase their potential for addiction and abuse and they are often found in combination with other drugs in drug-related fatalities ${ }^{8}$. For these reasons, the simultaneous analysis of benzodiazepines and their metabolites in biological fluids is of great interest to clinicians and forensic toxicologists.

Diazepam (7-chloro-1,3-dihydro-1-methyl-5-phenyl-2H-1,4-benzodiazepin-2-one) is a benzodiazepine compound, which enhances the activity of gamma-aminobutyric acid, the most common inhibitory neurotransmitter in the central nervous system. It is used in the treatment of severe anxiety disorders, as a hypnotic in the short-term management of insomnia, as a sedative and premedicant, as an anticonvulsant and in the management of alcohol withdrawal syndrome?

In the therapy of major depressive syndromes, diazepam is often prescribed as an adjuvant to control anxious symptoms and to treat anxiety associated with the beginning of treatment with second-generation antidepressants ${ }^{10}$. Diazepam is a core medicine in the World Health Organization's (WHO) "Essential Drugs List", which is a list of minimum medical needs for a basic health care system ${ }^{11}$.

Like all 1,4-benzodiazepine drugs, diazepam acts by all osterically interacting with neuronal $\mathrm{GABA}_{\mathrm{A}}$ receptors, thus facilitating the interaction between the receptor and the neurotransmitter, which in turn leads to a decrease in neuronal activity. For this reason, benzodiazepines are generally considered much safer than the older sedative barbiturates (which are direct GABA agonists), especially in case of overdose. However, side effect such as somnolence, amnesia, dizziness and impaired concentration are commonly reported. Furthermore, diazepam and other benzodiazepines induce tolerance during chronic administration and an abstinence syndrome upon discontinuation. Consequently, pure Diazepam is considered a controlled substance in several Western countries (it is a schedule IV drug according to the convention on psychotropic substances) ${ }^{12}$.

The role of reactive oxygen species (ROS) have been implicated in tissue injury. These continuously produced ROS are scavenged by SOD, glutathione peroxidase (GSH-Px) and catalase (CAT). Malondialdehyde (MDA) is the breakdown product of the major chain reactions leading to oxidation of polyunsaturated fatty acids and thus serves as a reliable marker of oxidative stress-mediated lipid peroxidation ${ }^{13}$. In this study was to investigate the effect on antioxidant enzymes and malondialdehyde (MDA) in rat serum and various tissues of chronic diazepam application.

\section{Experimental}

Animals were purchased from the Inonu University Laboratory Animal Resource Center. In this study, 26 female Wistar-Albino rats (3 months old) weighing $200 \pm 20$ g were used. Rats were randomly divided into two groups of ten rats each as following: diazem drug group (DiD) and control group (C). All animals were housed in standard animal laboratory conditions (12:12 h light-dark cycle, temperature $22 \pm 2{ }^{\circ} \mathrm{C}$ and humidity $50 \pm 5 \%$ ). Rats were exposed to diazepam and determination of the change in enzyme activity levels was aimed in this six-week study. Diazepam, respectively in $1 \mathrm{mg} / \mathrm{kg}$ doses, was given intraperitonally twice a day for six weeks.

All experiments in this study were performed in accordance with the guidelines for animal research from the National Institute of Health and approved by the Committee on Animal Research at Inonu University, Malatya. 


\section{Homogenization}

Tissues were homogenized (PCV Kinematical Status Homogenizator) in ice cold phosphate buffered saline $(\mathrm{pH}$ 7.4). The homogenate was sonified with an ultrasonifier (Bronson Sonifier 450 ) by 3 cycles (20-s sonications and 40-s pause on ice). The homogenate was centrifuged $\left(15,000 \times g, 10 \mathrm{~min}, 4{ }^{\circ} \mathrm{C}\right)$ and cell-free supernatant was subjected to enzyme assay immediately. For lipid peroxidation analysis the tissue was washed three times with ice cold $0.9 \% \mathrm{NaCl}$ solution and homogenized in $1.15 \mathrm{KCl}$. The homogenates were subjected to lipid peroxidation assay immediately. Serum samples were subjected to enzymes analysis and lipid peroxidation assay immediately.

\section{Determination of enzymes activities}

The enzymes catalase (CAT), superoxide dismutase (SOD) and glutathione peroxidase (GSH-Px) were determined spectrophotometrically. CAT activity was measured at $37{ }^{\circ} \mathrm{C}$ by following the rate of disappearance of $\mathrm{H}_{2} \mathrm{O}_{2}$ at $240 \mathrm{~nm}\left(\varepsilon_{240}=40 \mathrm{M}^{-1} \mathrm{~cm}^{-1}\right)^{14}$. One unit of catalase activity is defined as the amount of enzyme catalyzing the degradation of $1 \mu \mathrm{mol}$ of $\mathrm{H}_{2} \mathrm{O}_{2} /$ min at $37{ }^{\circ} \mathrm{C}$. CAT activity was expressed as $\mathrm{U} / \mathrm{mg}$ protein in the tissue.
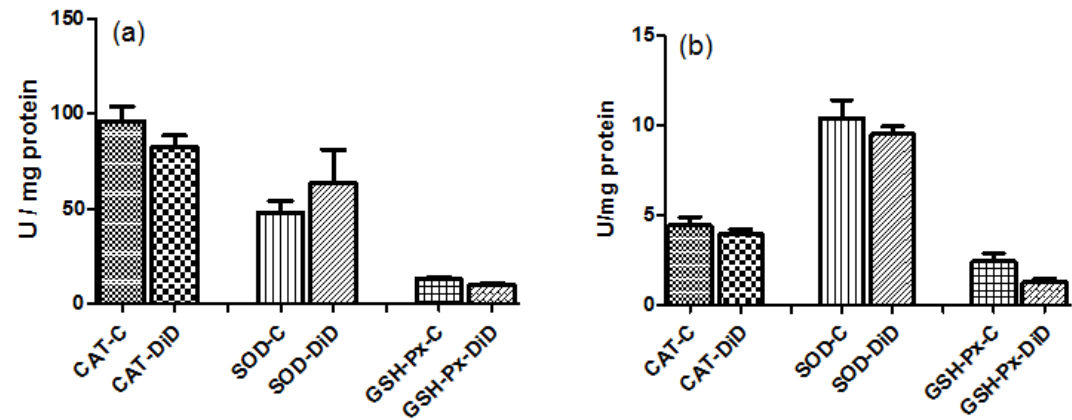

Figure 1. Different enzyme activity in rat (a) kidney and (b) brain

SOD $(\mathrm{Cu}, \mathrm{Zn}-\mathrm{SOD})$ activity in the supernatant was measured using xanthine oxidase/cytochrome c by method ${ }^{15}$. 1 unit (U) of activity is the amount of enzyme needed to cause half-maximal inhibition of cytochrome c reduction. The amount of SOD in the extract was determined as units / $\mathrm{mg}$ protein, utilizing a commercial SOD as the standard.
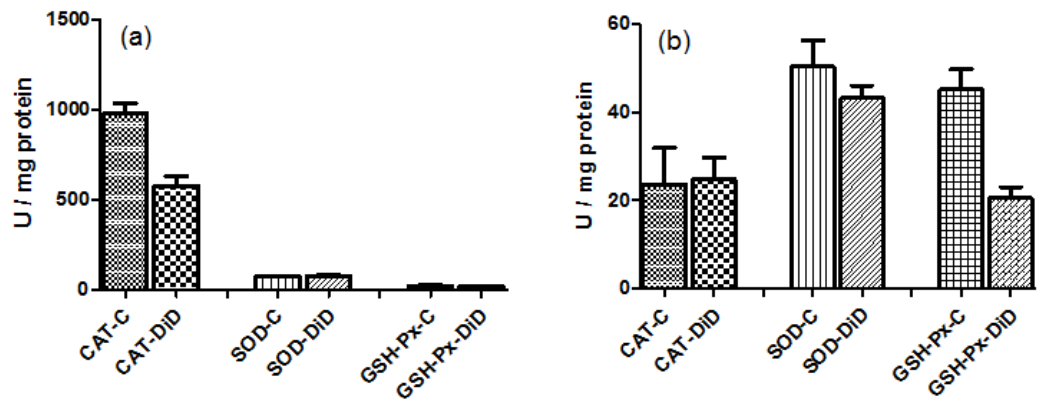

Figure 2. Different enzyme activity in rat (a) liver and (b) serum

Glutathione peroxidase GSH-Px activity was determined in a coupled assay with glutathione reductase and by measuring the rate of NADPH oxidation at $340 \mathrm{~nm}$ using hydrogen peroxide as the substrate ${ }^{16}$. Specific activity is given as $\mu \mathrm{mol} \mathrm{NADPH}$ disappeared $\mathrm{min}^{-1} \mathrm{mg}^{-1}$ protein. 


\section{MDA assay}

As a marker of lipid peroxidation production, the MDA concentration was measured as described $^{17}$ with a minor modification. The reaction mixture was prepared by adding $250 \mu \mathrm{L}$ homogenate or serum into $2 \mathrm{~mL}$ reaction solution $(15 \%$ trichloroacetic acid: $0.375 \%$ thiobarbituric acid: $0.25 \mathrm{~N} \mathrm{HCl}, 1: 1: 1, \mathrm{w} / \mathrm{v}$ ) and heated at $100{ }^{\circ} \mathrm{C}$ for $30 \mathrm{~min}$. The mixture was cooled to room temperature, centrifuged $(10,000 \mathrm{~g}$ for $10 \mathrm{~min})$ and the absorbance of the supernatant was recorded at $532 \mathrm{~nm}$. MDA results were expressed as nmol/mg protein in the homogenate.

\section{Determination of protein}

Protein levels of the serum and tissue samples were measured by the Bradford method ${ }^{18}$. The absorbance measurement was taken at $595 \mathrm{~nm}$ using a UV-Vis spectrophotometer. Bovine serum albumin (BSA) was used as protein standard.

\section{Statistical analysis}

Biochemical data were given as the mean \pm standard deviation. The one-way analysis of variance (ANOVA) and Turkey's multiple comparison tests were used to analyze the significance of the differences between the control and experimental groups. The differences between the groups were evaluated by Duncan post test. A $p$ value of less than 0.05 was considered to be significant. All analyses were performed using the Statistical Package for the Social Sciences (SPSS) software in a PC-compatible computer.

\section{Results and Discussion}

Benzodiazepines, such as diazepam (trade name is Valium, chemically it is phenyl benzodiazepine containing 7-chlor-1,3-dihydro-1-methyl-5-phenyl-2H-1,4 benzodiazepine) are commonly used for their anxiolytic and sedative effects, that is, by their action on high-affinity receptor sites coupled to the $\gamma$-amino butyric acid A receptor complex, present in the central nervous system ${ }^{19}$. Nevertheless, in addition to the central receptors described for benzodiazepine, peripheral-type binding sites have been identified for them in liver cells ${ }^{20}$, endocrine steroidogenic tissues ${ }^{21}$ and immune cells, such as macrophages and lymphocytes ${ }^{22}$ and also in tumor cells ${ }^{23}$. Peripheral type benzodiazepine receptor expression has been shown to increase in some neoplastic tissues and tumor cells, particularly in the liver ${ }^{24}$, ovary ${ }^{25}$, colon $^{26}$, breast ${ }^{27}$ and in the brain ${ }^{28}$. Many studies have been conducted to ascertain any role and/or involvement of free radical mediated pro-oxidative processes in following diazepam administration ${ }^{29}$.

Oxidative stress is known to be a component of molecular and cellular damage mechanism in a wide spectrum of human diseases ${ }^{30-33}$. The OS generally describes a condition in which cellular antioxidant defenses are inadequate to completely detoxify the free radicals being generated, due to excessive production on ROS, loss of antioxidant defenses or, both ${ }^{34}$. This condition may occur locally, as antioxidant defenses may become overwhelmed at certain sub cellular locations while remaining intact overall and selectively with regard to radical species, as antioxidant defenses are radical-specific, for example, superoxide dismutase (SOD) for superoxide and catalase or glutathione peroxidase for $\mathrm{H}_{2} \mathrm{O}_{2}{ }^{35}$.

In humans, studies using flumazenil have found evidence for dissociation between the sedative and amnestic effects of several different benzodiazepines ${ }^{36,37}$. These findings suggest that there may be additional mechanism to be involved in benzodiazepines induced anterograde amnesia. It was shown that diazepam caused an enhanced malondialdehyde (MDA) formation along with decreased superoxide dismutase (SOD) activity and glutathione reductase GSH-Px activity in the cerebrum of rat following excessive formation of reactive oxygen species $^{38}$. The brain is particularly vulnerable to oxidative stress because it consumes 
large amounts of oxygen, has abundant lipid content, yet maintains relative paucity of antioxidant levels compared with other organs ${ }^{39}$. Suggesting that diazepam has an important role in development of oxidative stress in brains and livers of diazepam-treated rats ${ }^{40}$. The changes in both biochemical analysis as well as the in histological pictures in liver kidney and heart were severing in animals left for 30 days after diazepam ingestion. In the light of these results, it can be suggested that diazepam is a hazards drug and an oxidative stress inducer ${ }^{40}$. However, there is no evidence in the literature indicating the role of DZP on oxidative stress in rats.

The xenobiotic, taken from the outside into our liver, recognized as the center of the body metabolism is the main tissue where the drugs undergo changes. Within the framework of the relevant study, a significant decrease in all groups at MDA level was detected in comparison with the control group $(\mathrm{p}<0.05)$, while a significant increase the control group at CAT activity was observed in comparison with the all other groups $(\mathrm{p}<0.05)$. A statistically significant decrease was also observed in the group administered diazem in comparison with the conveyor group of diazem, which can explained through the fact that free radical damage may occur in the groups, aside from the control group. Although a certain level of increase was detected in the groups at SOD activity, aside from the control group, it is not statistically significant. In terms of GSH-P $\mathrm{P}_{\mathrm{x}}$ activity, the increase in the other group was regarded as statistically significant aside from the decrease in the groups administered diazem.

Table 1 show that diazepam application results of enzyme activity in rat serum, brain, kidney and liver $(n=6)$. Within the brain tissue, no significant change was observed in the group administered diazem at MDA level in comparison with the control group ( $>00.05)$. However, a significant decrease was observed in the conveyor group $(p<0.05)$. It was established that such dosage of the drug didn't lead to lipid peroxidation. While no change was observed at CAT and SOD values, the relevant changes weren't statistically significant. In terms of the GSH- $\mathrm{P}_{\mathrm{x}}$ activity, the enzyme activity in the control group showed a significant increase in comparison with the all other groups $(\mathrm{p}<0.05)$. This change at GSHPx occurs through the information stating that this enzyme functions in the cases of the formation of hydrogen peroxide at the law concentration of the cell.

Table 1. Diazepam application results of enzyme activity in rat serum, brain, kidney and liver.

\begin{tabular}{cccccc}
\hline Enzyme Activity & & Serum & Brain & Kidney & Liver \\
\hline \multirow{2}{*}{ CAT(U/mg Protein) } & C & $23.58 \pm 8.29$ & $4.42 \pm 0.48$ & $95.76 \pm 7.76$ & $977.77 \pm 57.23$ \\
& DiD & $24.83 \pm 4.9^{\mathbf{a}}$ & $3.98 \pm 0.24^{\mathrm{a}}$ & $82.37 \pm 5.98^{\mathrm{a}}$ & $576.18 \pm 52.94^{\mathrm{a}}$ \\
\multirow{2}{*}{ SOD (U/mg Protein) } & $\mathrm{C}$ & $50.25 \pm 5.98$ & $0.41 \pm 0.99$ & $47.58 \pm 6.57$ & $71.37 \pm 3.01$ \\
& $\mathrm{DiD}$ & $43.13 \pm 2.92^{\mathrm{a}}$ & $9.51 \pm 0.43^{\mathrm{a}}$ & $63.32 \pm 17.79^{\mathrm{a}}$ & $76.34 \pm 3.87^{\mathrm{a}}$ \\
\multirow{2}{*}{ GSH-Px(U/mg Protein) } & $\mathrm{C}$ & $45.06 \pm 4.68$ & $2.42 \pm 0.42$ & $12.96 \pm 0.98$ & $20.91 \pm 1.62$ \\
& $\mathrm{DiD}$ & $20.52 \pm 2.52^{\mathrm{a}}$ & $1.28 \pm 1.81^{\mathrm{a}}$ & $10.01 \pm 0.67^{\mathrm{a}}$ & $17.88 \pm 2.73^{\mathrm{a}}$ \\
\hline
\end{tabular}

Data are expressed as mean $\pm S E(n=6) .{ }^{a}$ Significantly different from diazepam drug(DiD) vs. control group $\mathbb{C},(p<0.05)$.

Within the renal tissue, a significant decrease was observed in the diazem group at MDA levels in comparison with the control group $(\mathrm{p}<0.05)$. The results acquired from the MDA levels indicated that no significant increase in lipid peroxidation was observed. According to the enzyme activity results, no changes were observed at CAT and SOD values and moreover the relevant changes weren't statistically significant. In terms of the GSH-P $\mathrm{x}_{\mathrm{x}}$ activity, while the control group highlighted the highest activities, a statistically significant decrease was observed in the other groups. 
In the light of the sample of serum, a decrease at MDA level was enshrined within the statistically same group. While the control group of the SOD enzyme activity and the groups administered diazem were under the statistically same group, the decreases in the other group was significant in comparison with the control group $(\mathrm{p}<0.05)$. The CAT and SOD results indicated a change in the level of the free radical formation at blood parameters in terms of the group administered diazem (Table 2). In terms of the GSH-P $\mathrm{P}_{\mathrm{x}}$ activity, a significant decrease in the group administered diazem was observed in comparison with the control group $(\mathrm{p}<0.05)$.

Table 2. Diazepam application results of MDA and protein in rat serum, brain, kidney and liver.

\begin{tabular}{lrcccc}
\hline $\begin{array}{c}\text { Biochemical } \\
\text { Parameters }\end{array}$ & & Serum & Brain & Kidney & Liver \\
\hline MDA (nmol/mg & C & $3.31 \pm 0.02$ & $4.39 \pm 0.57$ & $2.23 \pm 0.02$ & $1.05 \pm 0.03$ \\
Protein) & DiD & $3.15 \pm 0.21$ & $3.65 \pm 0.32^{\mathrm{a}}$ & $1.54 \pm 0.07^{\mathrm{a}}$ & $0.95 \pm 0.06^{\mathrm{a}}$ \\
Protein $(\mathrm{mg} / \mathrm{mL})$ & $\mathrm{C}$ & $1.30 \pm 0.01$ & $4.05 \pm 0.04$ & $3.69 \pm 0.05$ & $5.37 \pm 0.04$ \\
& DiD & $1.31 \pm 0.02$ & $440 \pm 0.09$ & $4.43 \pm 0.02^{\mathrm{a}}$ & $4.56 \pm 0.02^{\mathrm{a}}$ \\
\hline
\end{tabular}

Data are expressed as mean $\pm S E(n=6) .{ }^{a}$ Significantly different from diazepam drug(DiD) vs. control $\operatorname{group}(C),(p<0.05)$.

By means of drug applications, a number of changes were observed within the tissues and serum at enzyme activity level and that of MDA. Although such changes seem unparalleled with each other, they may be explained, as they lead to a certain level of free radical formation. Furthermore, it was concluded that the dosages of drugs should be at different levels and the chronic application process should be longer in order to set out the effects of the drugs clearly.

\section{References}

1. Marin S J, Rebecka C, Merrell M and McMillin G A, J Anal Toxicol., 2008, 32(7), 491-498; DOI:10.1093/jat/32.7.491.

2. Ngwa G, Fritch D, Blum K and Newland G, J Anal Toxicol, 2007, 31(7), 369-376; DOI:10.1093/jat/31.7.369.

3. Schultz H, Benzodiazepines, Springer Verlag, Heidelberg, 1982.

4. Benzodiazepines-A Medical Dictionary, Bibliography and Annotated Research Guide to Internet Refer, Icon Group International, Inc, San Diego, 2004.

5. Roy-Byrne P P and Cowley D S, Benzodiazepines in Clinical Practice: Risks and Benefits. American Psychiatric Press: Washington, DC, 1991.

6. Pirnay S, Ricordel I, Libong D and Bouchonnet S, J Chromatogr A, 2002, 954, 235-245.

7. Wafford K A and Ebert B, Nat Rev Drug Dis., 2008, 7, 530-540;

DOI: $10.1038 / \mathrm{nrd} 2464$

8. Drummer O H, Forensic Sci Int., 2004, 142(2), 101-113;

DOI:10.1016/j.forsciint.2004.02.013.

9. Reynolds J E F, (Ed.), Martindale: The Extra Pharmacopoeia, 30 ${ }^{\text {th }}$ Ed., Pharmaceutical Press, London, 1993, 71-72.

10. Zienowicz M, Wisłowska-Stanek A, Lehner M, Taracha E, Maciejak P, Sobolewska A, Szyndler J, Turzynska D, Walkowiak J and Płaznik A, Pharmacol Rep., 2006, 58, 115-119. 
11. WHO Model List of Essential Medicines (15 ${ }^{\text {th }}$ Ed.), World Health Organization, Geneva, 2007.

12. List of Psychotropic Substances Under International Control $\left(47^{\text {th }}\right.$ Ed.), International Narcotics Control Board, Vienna, 2007.

13. Draper H H and Hadley M, Methods Enzymol., 1990, 186, 421-431.

14. Luck H, Peroxidase. In: Methods of enzymatic analysis (Ed., Bergmeyer H U), Academic Press, New York and London, 1963, 895-897.

15. McCord J M and Fridovich I, J Biol Chem., 1969, 244, 6049-6055.

16. Lawrence R A and Burk R F, Biochem Biophys Res Commun., 1976, 71(4), 952-958.

17. Buege J A and Aust S D, Methods Enzymol., 1978, 52, 302-310.

18. Bradford M M, Anal Biochem., 1976, 72(1-2), 248-254.

19. Costa E, Guidotti A, Mao C C and Suria A, Life Sci., 1975, 17(2), 167-185.

20. Woods M J, Zisterer D M and Williams D C, Biochem Pharmacol., 1996, 51(10), 1283-1292.

21. Zilz A, Li H, Castello R, Papadopoulos V and Widmaier E P, Endocrinology, 1999, 140(2), 859-864; DOI:10.1210/en.140.2.859.

22. Zavala F, Pharmacol Therap, 1997, 75(3), 199-216.

23. Han Z, Slack R S, Li W and Papadopoulos V, J Recept Signal Transduct Res., 2003, 23(2-3), 225-38.

24. Venturini I, Alho H, Podkletnova I, Corsi L, Rybnikova E, Pellicci R, Baraldi M, Pelto- Huikko M, Helen P and Zeneroli M L, Life Sci., 1999, 65(21), 2223-2231.

25. Katz Y, Benbaruch G, Kloog Y, Menczer J and Gavish M, Clin Sci., 1990, 78, 155-158; DOI:10.1042/cs0780155.

26. Katz Y, Eitan A and Gavish M, Oncology, 1990, 47(2), 139-142.

27. Hardwick M, Fertikh D, Culty M, Li H, Vidic B and Papadopoulos V, Cancer Res., 1999, 59, 831-842.

28. Miettinen H, Kononen J, Haapasalo H, Helen P, Sallinen P, Harjuntausta T, Helin H and Alho H, Cancer Res, 1995, 55(12), 2691-2695.

29. Musavi S and Kakkar P, Mol Cell Biochem., 2003, 245(1-2), 51-56;

DIO:10.1023/A:1022857508987.

30. Halliwell B, Drugs Aging., 2001, 18(9), 685-716;

DOI:10.2165/00002512-200118090-00004.

31. Halliwell B and Gutteridge J M C, Free radicals in biology and medicine. Oxford University Press, New York, 2007, 936.

32. Dalle Donne I, Rossi R, Colombo R, Giustarini D and Milzani A, Clin Chem., 2006, 52()4, 601-623; DOI:10.1373/clinchem.2005.061408.

33. Videla L A, World J Hepatol., 2009, 1(1), 72-78; DOI:10.4254/wjh.v1.i1.72.

34. Davies K J, Biochem Soc Symp., 1995, 61, 1-31.

35. Siegel G J, Agranoff B W, Basic Neurochemistry: Molecular, Cellular and Medical Aspects, Sixth Ed., Lippincott Williams \& Wilkins, 1999

36. Ghoneim M M, Dembo J B and Block R I, Anesthesiology, 1989, 70(6), 899-904.

37. Curran H V and Birch B, Psychopharmacology, 1991, 103, 519-523.

38. Musavi S and Kakkar P, Mol Cell Biochem., 1998, 178(1-2), 41-46.

39. Halliwell B, J Neurochem., 2012, 120(5), 850;

DOI:10.1111/j.1471-4159.2011.07627.x.

40. Abdelmajeed N A, Res J Medicine Med Sci., 2009, 4, 295-302. 